\title{
Studies on Lactate Dehydrogenase (LDH) Activity in the Pupal and Adult Stages of the Silkworm Bombyx Mori L.
}

\author{
M.N. Ramya* and T.S. Jagadeesh Kumar \\ Silkworm Physiology and Biochemistry Laboratory,Department of Studies in Sericulture \\ Science, Manasagangothri, University of Mysore, Mysuru, Karnataka, India \\ *Corresponding author
}

\section{A B S T R A C T}

\section{Keywords}

LDH, Activity profile, Bivoltine, multivoltine, Silkworm, Bombyx mori $\mathrm{L}$.

\section{Article Info}

Accepted: 26 October 2019 Available Online: 10 November 2019
The present study was carried out to understand the Lactate dehydrogenage (LDH) activity in the pupal and adult stages in four popular silkworm bivoltine breeds namely, $\mathrm{CSR}_{2}$, $\mathrm{NB}_{4} \mathrm{D}_{2}, \mathrm{APS} 45$ and APS12 and four multivoltine races namely, PM, C.nichi, APM1 and APM3 were collected from the Germplasm Bank of Department of Studies in Sericultural Sciences, University of Mysore, Mysuru, and APSSRDI, Hindupur, Andhra Pradesh. Layings were prepared and the eggs were incubated at $25 \pm 1^{\circ} \mathrm{c}$ temperature and reared by adopting the standard methods. The male and female silkworm were separated during $5^{\text {th }}$ instar just after resuming from $4^{\text {th }}$ moult before feeding to get virgin female and unmated male and to identify the male and female pupae on $3^{\text {rd }}$ day after spinning during pupal stage. Further, the good cocoons were selected for further assessment and utilization. The fat body samples were extracted from male and female pupal stage of $3^{\text {rd }}$ day to till last day of pupal duration. Virgin and mated male and female of the silkworm adult stage from $1^{\text {st }}$ day to till last day of adult life span. The extracted samples were kept at $-20^{\circ} \mathrm{c}$ for preservation and further, utilization for the analysis of enzyme profiles of Lactate dedyhrogenase (LDH).The results obtained from the present study clearly showed, the activity profiles of the fat body LDH is a dynamic enzyme depicted the maximum level of activity in each and every day of male and female pupation period observed a sequential quantum of differences in the order of marginal increase were noticed. Further, the LDH enzyme activity profile was observed more in virgin female moth of bivoltine races/breeds than multivoltine races. However, the enzymes are very active for the synthesis of reactive oxygen species leads to the release of free radicals and even antioxidant accelerates the rate of reaction under the extreme environmental conditions. The results obtained from the present investigation are the document for an empirical analysis in the fat body tissue of healthy pupae and adult stages of different breeds/races of the silkworm Bombyx mori $\mathrm{L}$.

\section{Introduction}

Silkworm is a most suitable laboratory tool and appropriate insect to study the longevity is one among all other insects are concern, because it has several benefits, its shorter life cycle, physiological/biological mechanism, etc., are needed to understand the concept. In 
this regard a gerontologist, Rockstein, (1973) has suggested that, the shorter the life cycles of animals/organisms/insects have highly desirable to study the lifespan.

In general, the organismic tissue differentiation followed by cellular respiration, mobilization and the utilization of complex food molecules in the fat body is noticed a inter conversion from one cell to other cells is noted that physiological process therefore, each and every organism on the earth sustainability continuation and reproduction is basically interlinked with the cellular metabolic basis of energy production dependent active biomolecules. The ingestion of food digestion, absorption followed by assimilation is the order of metabolism of each stage of conversion from one form to another form is closely related to activity profiles of enzymes unless the activity of enzymes profusely influenced to the target cells in order to activate the functioning of the cells, tissues and organismic expression depends on the level of activity of enzyme profiles.

India has been a tropical country with a great degree of variation in temperature (Pillai and Krishnaswamy, 1987). The temperature affects the biochemical reactions by kinetic and conformational changes in a series of enzymes (Somme, 1972; Alexandrov, 1977 and Reddy and Benchanmin, 1992). Sen et al., (1976) and Siddiqui et al., (1984) reported that, the any population from different region attributes tremendous differences in the expression of commercial characters and difference population exhibits significant diversity in physiological, genetic and behavioral pattern accordingly with the existing local ecological situation. The intake of food tasar silkworm, Antheraea mylitta reaches its peak with the body growth, development and metabolism (Jolly et al., 1974). The supply of metabolize for energy production (Sacktor, 1974) is regulated by the enzymes interconnecting protein and carbohydrate metabolism (Katunuma et al., 1968). In the present approach of a study is related to certain key enzymes are most active and considered as sensitive in-dices of preparatory phase during larva, pupal and adult stages of the silkworm, Bombyx mori. It is noteworthy that, the enzymatic basis of development in view of pupal and adult longevity is the most consequences for the expression of commercial characters. There are different enzymes are considered as major indices and among all the lactate dehydrogenase to emphasize the cellular, sub cellular level of activity in fat body tissue is a major organ system from which the energy storage distributed to the different cells of the organisms for the developmental, behavioral, morphological and physiological adaptation under different situation. Keeping in view the above said enzyme taken up for the quantitative observational changes is represented in the tables 1 to 6 and figures 1 to 12 in this chapter.

\section{Materials and Methods}

Four popular bivoltine breeds namely, $\mathrm{CSR}_{2}$, $\mathrm{NB}_{4} \mathrm{D}_{2}$, APS45 and APS12 and four multivoltine races namely, PM, C.nichi, APM1 and APM3 were collected from the germplasm banks of Department of Studies in Sericulture Science, University of Mysore, Mysuru, and APSSRDI, Hindupur, Andhra Pradesh and the layings were prepared and the eggs were incubated at $25 \pm 1^{\circ} \mathrm{C}$ temperature and $80-85 \%$ relative humidity for about 10 days till their hatching and reared by adopting the methods described by Tazima (1978) and Krishna swami, (1978) and the good cocoons were selected for further assessment. The male and female sex were separated during $5^{\text {th }}$ instar just after resuming from $4^{\text {th }}$ moult before feeding to get virgin female and unmated male and to identify the male and female pupae on $3^{\text {rd }}$ day after spinning during 
pupal stage. The fat body samples were extracted from male and female pupae and virgin and mated female and unmated and mated male of silkworm adult stages of $3^{\text {rd }}$ day to till last of pupal duration and $1^{\text {st }}$ day to till last of adult life span respectively. The extracted samples were kept at $-20^{\circ} \mathrm{C}$ for preservation and utilization for the analysis of Lactate dedyhrogenase (LDH) enzyme profiles.

Lactate dedydrogenase (LDH) activity (EC: 1.3.99.2)

Systematic name: Lactate oxide reductase

L- alanine $+\alpha-$ Ketoglutrate $\leftrightarrow$ Pyruvated $+\alpha$ - glutamate

The activity level of lactate dedydrogenase was measured by colorimetric method of Nichlas et al., (1960). INT [(2-p-iodophenyl) - 3 - (p-nitrophenyl) - 5- phenyl tetrazolium chloride] was used as electron accepter. The level of enzyme activity was estimated in the fat body tissue of bivoltine and multivoltine silkworm races/breeds. $50 \mathrm{mg}$ of each sample was homogenized in $1 \mathrm{ml}$ of cold sucrose solution $(0.25 \mathrm{M})$ was centrifuged at $3000 \mathrm{rpm}$ for 15 minutes. The supernatant was used as source of enzyme.

$\begin{array}{ll}\text { Phosphate buffer }\left(\mathrm{P}^{\mathrm{H}}=7.4\right) & 100 \mu \text { moles } \\ \text { INT } & 10 \mu \text { moles } \\ \text { Lithium lactate } & 50 \mu \text { moles } \\ \text { Enzyme extract } & 50 \mu \text { moles }\end{array}$

The reaction mixture was brought to $37^{\circ} \mathrm{C}$ in the water bath and enzyme extract was added. The mixture was incubated at $37^{\circ} \mathrm{C}$ for 60 minute along with a blank solution containing heat killed enzyme. The initiation of the enzyme action was indicated by development of red colour due to the formation of formazone. After 60 minutes of incubation, the reaction was stopped by adding $6 \mathrm{ml}$ of glacial acetic acid and $6 \mathrm{ml}$ of toluene to extract the red colour by storing the test tubes in refrigerated overnight. The intensity of colour was read at $495 \mathrm{~nm}$ in a spectrophotometer using blank solution. The enzyme activity was expressed in unit/mg protein.

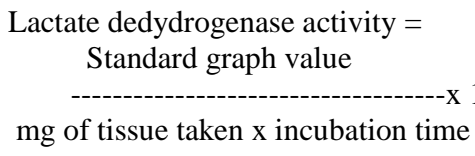

\section{Results and Discussion}

The activity profiles of enzymes in fat body tissue of non feeding stages namely, pupae and adult stage of $\mathrm{CSR}_{2}, \mathrm{NB}_{4} \mathrm{D}_{2}$, APS45 and APS12 represents biviltine breeds and similarly PM, C.nichi, APM1 and APM3 represents multivoltine strains in the present investigation to correlate the longevity represents work under taken to narrate the relationship among the two voltine groups. The quantum of changes in the activity of lactate dehydrogenase of male and female pupae of the selected races/breeds it is interesting to note that, the bivoltine breeds namely, $\mathrm{CSR}_{2}, \mathrm{NB}_{4} \mathrm{D}_{2}$, APS45 and APS12 are collectively showed the maximum proportion of the quantum of activity compare to the multivoltine strains such as PM, C.nichi, APM1 and APM3 especially in male pupae.

The female pupae tend to reveal an activity of lactate dehydrogenase in fat body tissue both in multivoltine and bivoltine strains. There was a consistent order of increase was observed in almost all the selected breeds/races and revealed a statistical differences at $\mathrm{CD}$ value of $5 \%$ in different days of developmental period among the silkworm breeds.

The changes in the fat body lactate dehydrogenase activity level of virgin and mated female moth enhanced represented in table 1 to 6 and figures 1 to 12 . It is noteworthy that, the virgin and mated female augmented with a steady increase to the maximum of $105 \mu$ moles of 
formazone/unit/mg of protein. The patterns of changes observed in the multivoltine strains are almost on par with the bivoltine breeds and the fat body lactate dehydrogenase activity level of the mated female moths of the bivoltine and multivoltine strains. Whereas, the unmated male moth the fat body lactate dehydrogenase activity level represents same trend of activity profiles of fat body lactate dehydrogenase. The mated male moth executed the phase and pattern of observationl changes the fat body lactate dehydrogenase among the bivoltine breeds and consistently maintained the highest level of activity profile compare to multivoltine strains among the all eight selected silkworm strains and APM3 showed longevity period of 9days when compare to the other mated male moths revealed only 8days of adult duration. It is a noteworthy that, the differences among the eight breeds/races the statistically significant CD @ 5\% levels. It was concluded that gradual rise in lactate dehydrogenase activity confirmed that as a rate limiting step in insect development. The unmated and mated male had relatively low lactate dehydrogenase activity compare to virgin and mated female. The activity profiles of fat body lactate dehydrogenase (LDH) is a dynamic enzyme depicted the maximum level of activity in each and every day of male and female pupation period showed a sequential quantum of differences in the order of marginal increase were noticed. The enzyme lactate dehydrogenase in virgin female moth of the bivoltine and multivoltine races/breeds illustrated that, more activity profile in bivoltine than multivoltine. The APM1 and APM3 showed more of activity compare to PM and C.nichi races. The same patterns of changes in the activity of lactate dehydrogenases were revealed in mated and unmated male moth of both multivoltine and bivoltine races/breeds. Among the male and female pupae, virgin and mated male and female adult stages of two voltine groups were substantiated an evidences in support of the screening of pupal and adult longevity period. However, these enzymes are very active for the synthesis of reactive oxygen species leads to the release of free radicals and even the antioxidant accelerates the rate of reaction under the extreme environmental condition.

Lactate dehydrogenase is the key enzyme involved in the anaerobic oxidation of $\mathrm{NADH}_{2}$ to NAD. The reaction occurs in the cytosol and the hydrogen atoms are received by pyruvate molecule reduced to lactate. C.servillia has nymphal instars in the life history. There was a steady rise in the total body lactate dehydrogenase which is gradual increase in the body weight was found. There was a sudden and significant rise in the total body lactate dehydrogenase activity level of $6^{\text {th }}$ instar nymph maintaining a rising trend in the adult insect. Thus there was sexwise variation in lactate dehydrogenase activity but lacking of the stage wise variation noted in $C$. servillia.

The fat body of adult female insect had a greater lactate dehydrogenase level than that of the adult male. The mature ovary/testis had much greater lactate dehydrogenase activity than that of immature ovary or testis. Overall rise in lactate dehydrogenase activity in all stage of both male and female might be due to their great dependence upon the energy produced glycolytically. The relative activities of dehydrogenase may also be related to the function and energy yielding demand of the tissues.

The finding is in accordance with the works of Chefurka (1965), Rekha et al., (2000), Kumar and Ehteshamuddin (2001), Srivastava et al., (1991), Zebe and Shan (1957). Raising in lactate dehydrogenase activity conforming the contention of that the lactate dehydrogenase was a rate limiting step in glycolysis in insects. 
Table.1Changes in fat body LDH activity level of male pupae of selected silkworm races (Each observation are expressed in $\mu$ moles of formazan/g protein/ h)

\begin{tabular}{|c|c|c|c|c|c|c|c|c|}
\hline $\begin{array}{l}\text { Races/breeds } \\
\text { Days }\end{array}$ & $\mathrm{CSR}_{2}$ & $\mathrm{NB}_{4} \mathbf{D}_{2}$ & APS45 & APS12 & PM & C.nichi & APM1 & APM3 \\
\hline 3 & $50.68 \pm 0.320$ & $49.34 \pm 0.557$ & $50.11 \pm 0.521$ & $49.66 \pm 0.474$ & $44.08 \pm 0.493$ & $43.63 \pm 0.381$ & $46.40 \pm 0.383$ & $46.19 \pm 0.376$ \\
\hline 4 & $52.51 \pm 0.294$ & $50.72 \pm 0.355$ & $52.01 \pm 0.549$ & $51.15 \pm 0.447$ & $46.05 \pm 0.462$ & $45.62 \pm 0.326$ & $47.30 \pm 0.311$ & $47.21 \pm 0.422$ \\
\hline 5 & $53.72 \pm 0.341$ & $51.39 \pm 0.382$ & $53.12 \pm 0.450$ & $52.44 \pm 0.400$ & $47.00 \pm 0.421$ & $46.25 \pm 0.369$ & $48.55 \pm 0.372$ & $48.17 \pm 0.539$ \\
\hline 6 & $55.25 \pm 0.390$ & $53.42 \pm 0.484$ & $54.55 \pm 0.495$ & $54.21 \pm 0.455$ & $48.27 \pm 0.394$ & $47.28 \pm 0.417$ & $50.44 \pm 0.539$ & $49.55 \pm 0.373$ \\
\hline 7 & $56.67 \pm 0.415$ & $54.64 \pm 0.334$ & $56.20 \pm 0.442$ & $55.48 \pm 0.360$ & $49.69 \pm 0.491$ & $48.63 \pm 0.350$ & $53.65 \pm 0.516$ & $51.43 \pm 0.417$ \\
\hline 8 & $58.06 \pm 0.479$ & $55.65 \pm 0.413$ & $57.30 \pm 0.609$ & $56.26 \pm 0.334$ & $51.29 \pm 0.559$ & $50.28 \pm 0.571$ & $54.65 \pm 0.337$ & $53.51 \pm 0.298$ \\
\hline 9 & $60.01 \pm 0.514$ & $57.33 \pm 0.604$ & $59.34 \pm 0.476$ & $58.19 \pm 0.455$ & $53.53 \pm 0.392$ & $52.52 \pm 0.347$ & $56.25 \pm 0.527$ & $55.49 \pm 0.415$ \\
\hline 10 & $64.14 \pm 0.553$ & $61.46 \pm 0.391$ & $63.69 \pm 0.360$ & $62.36 \pm 0.383$ & $55.43 \pm 0.407$ & 0.000 & $58.22 \pm 0.373$ & $57.25 \pm 0.616$ \\
\hline 11 & $67.23 \pm 0.429$ & $64.35 \pm 0.522$ & $66.58 \pm 0.391$ & $65.46 \pm 0.414$ & $57.42 \pm 0.417$ & 0.000 & $60.251 \pm 0.497$ & $59.43 \pm 0.415$ \\
\hline 12 & $68.14 \pm 0.558$ & $65.51 \pm 0.558$ & $67.39 \pm 0.364$ & $66.30 \pm 0.426$ & $59.56 \pm 0.420$ & 0.000 & 0.000 & 0.000 \\
\hline F-test & $*$ & $*$ & $*$ & $*$ & $*$ & $*$ & $*$ & $*$ \\
\hline C.D@ 5\% & 1.303 & 1.393 & 1.403 & 1.239 & 1.333 & 0.999 & 1.23 & 1.237 \\
\hline C.V. (\%) & 1.296 & 1.441 & 1.409 & 1.264 & 1.517 & 1.742 & 1.508 & 1.541 \\
\hline
\end{tabular}

Each values are the mean \pm SD of 3 replications, $P<0.05 \%$ : Significant $(*), P>0.05 \%$ : Non significant (NS) 
Table. 2 Changes in fat body LDH activity level of female pupae of selected silkworm races (Each observation are expressed in $\mu$ moles of formazan/g protein/h)

\begin{tabular}{|c|c|c|c|c|c|c|c|c|}
\hline $\begin{array}{c}\text { Races/breeds } \\
\text { Days }\end{array}$ & $\mathrm{CSR}_{2}$ & $\mathrm{NB}_{4} \mathrm{D}_{2}$ & APS45 & APS12 & PM & C.nichi & APM1 & APM3 \\
\hline 3 & $51.35 \pm 0.434$ & $50.43 \pm 0.399$ & $51.24 \pm 0.491$ & $50.73 \pm 0.371$ & $45.32 \pm 0.463$ & $44.62 \pm 0.509$ & $47.57 \pm 0.551$ & $46.90 \pm 0.462$ \\
\hline 4 & $53.48 \pm 0.358$ & $52.14 \pm 0.375$ & $52.75 \pm 0.376$ & $52.35 \pm 0.427$ & $46.89 \pm 0.433$ & $46.13 \pm 0.468$ & $48.81 \pm 0.417$ & $47.38 \pm 0.443$ \\
\hline 5 & $55.22 \pm 0.376$ & $53.66 \pm 0.298$ & $54.77 \pm 0.339$ & $54.19 \pm 0.541$ & $47.46 \pm 0.460$ & $46.88 \pm 0.462$ & $50.47 \pm 0.654$ & $49.47 \pm 0.598$ \\
\hline 6 & $56.52 \pm 0.330$ & $54.73 \pm 0.351$ & $56.09 \pm 0.504$ & $55.55 \pm 0.298$ & $49.19 \pm 0.487$ & $48.68 \pm 0.519$ & $52.19 \pm 0.525$ & $50.43 \pm 0.606$ \\
\hline 7 & $57.33 \pm 0.362$ & $55.30 \pm 0.362$ & $56.72 \pm 0.379$ & $56.16 \pm 0.444$ & $50.48 \pm 0.702$ & $49.29 \pm 0.541$ & $54.40 \pm 0.556$ & $52.15 \pm 0.471$ \\
\hline 8 & $59.50 \pm 0.348$ & $57.25 \pm 0.455$ & $59.19 \pm 0.493$ & $58.21 \pm 0.578$ & $52.21 \pm 0.478$ & $51.56 \pm 0.459$ & $55.79 \pm 0.324$ & $55.32 \pm 0.536$ \\
\hline 9 & $61.46 \pm 0.400$ & $58.10 \pm 0.512$ & $60.42 \pm 0.606$ & $58.82 \pm 0.410$ & $54.58 \pm 0.540$ & $53.47 \pm 0.648$ & $57.25 \pm 0.552$ & $56.37 \pm 0.675$ \\
\hline 10 & $65.38 \pm 0.348$ & $62.53 \pm 0.355$ & $65.16 \pm 0.397$ & $63.35 \pm 0.496$ & $56.27 \pm 0.525$ & 0.000 & $59.34 \pm 0.479$ & $58.38 \pm 0.530$ \\
\hline 11 & $67.71 \pm 0.364$ & $65.48 \pm 0.361$ & $67.31 \pm 0.514$ & $66.56 \pm 0.365$ & $59.47 \pm 0.391$ & 0.000 & $62.22 \pm 0.487$ & $61.70 \pm 0.670$ \\
\hline 12 & $70.22 \pm 0.425$ & $67.36 \pm 0.369$ & $69.67 \pm 0.380$ & $68.50 \pm 0.770$ & $62.52 \pm 0.414$ & 0.000 & 0.000 & 0.000 \\
\hline F-test & $*$ & $*$ & $*$ & $*$ & $*$ & $*$ & $*$ & $*$ \\
\hline C.D@ 5\% & 1.117 & 1.152 & 1.352 & 1.447 & 1.475 & 1.289 & 1.445 & 1.580 \\
\hline C.V. (\%) & 1.089 & 1.164 & 1.329 & 1.444 & 1.639 & 2.207 & 1.726 & 1.927 \\
\hline
\end{tabular}

Each values are the mean \pm SD of 3 replications, $P<0.05 \%$ : Significant $(*), P>0.05 \%$ : Non significant (NS) 
Table.3 Changes in fat body LDH activity level of virgin female moths of selected silkworm races (Each observation are expressed in $\mu$ moles offormazan/ $\mathrm{g}$ protein / h)

\begin{tabular}{|c|c|c|c|c|c|c|c|c|}
\hline $\begin{array}{c}\text { Races/breeds } \\
\text { Days }\end{array}$ & $\mathbf{C S R}_{\mathbf{2}}$ & $\mathbf{N B}_{\mathbf{4}} \mathbf{D}_{\mathbf{2}}$ & APS45 & APS12 & PM & AP.nichi & APM1 \\
\hline $\mathbf{1}$ & $80.53 \pm 0.669$ & $78.71 \pm 0.614$ & $79.26 \pm 0.587$ & $78.79 \pm 0.340$ & $64.25 \pm 0.576$ & $64.04 \pm 0.247$ & $70.49 \pm 0.615$ & $69.38 \pm 0.663$ \\
\hline $\mathbf{2}$ & $82.35 \pm 0.628$ & $80.38 \pm 0.571$ & $81.46 \pm 0.669$ & $81.05 \pm 0.476$ & $69.22 \pm 0.582$ & $65.81 \pm 0.338$ & $72.64 \pm 0.666$ & $71.74 \pm 0.480$ \\
\hline $\mathbf{3}$ & $85.43 \pm 0.542$ & $83.14 \pm 0.288$ & $84.50 \pm 0.705$ & $84.10 \pm 0.527$ & $71.43 \pm 0.578$ & $68.28 \pm 0.554$ & $73.48 \pm 0.543$ & $73.50 \pm 0.621$ \\
\hline $\mathbf{4}$ & $87.42 \pm 0.587$ & $86.53 \pm 0.722$ & $87.25 \pm 0.579$ & $85.99 \pm 0.895$ & $73.34 \pm 0.477$ & $70.30 \pm 0.532$ & $75.47 \pm 0.398$ & $74.40 \pm 0.454$ \\
\hline $\mathbf{5}$ & $89.19 \pm 0.644$ & $86.81 \pm 0.608$ & $88.51 \pm 0.509$ & $87.45 \pm 0.608$ & $74.39 \pm 0.505$ & $73.58 \pm 0.786$ & $76.65 \pm 0.363$ & $75.35 \pm 0.558$ \\
\hline $\mathbf{6}$ & $92.54 \pm 0.517$ & $90.29 \pm 0.581$ & $91.57 \pm 0.689$ & $91.05 \pm 0.531$ & $75.45 \pm 0.675$ & $74.19 \pm 0.672$ & $79.04 \pm 0.466$ & $78.44 \pm 0.477$ \\
\hline $\mathbf{7}$ & $96.44 \pm 0.748$ & $93.48 \pm 0.482$ & $95.49 \pm 0.601$ & $94.29 \pm 0.608$ & $78.18 \pm 0.513$ & $77.23 \pm 0.579$ & $81.43 \pm 0.696$ & $80.50 \pm 0.684$ \\
\hline $\mathbf{8}$ & $99.30 \pm 0.495$ & $97.29 \pm 0.638$ & $98.79 \pm 0.456$ & $98.18 \pm 0.580$ & $80.40 \pm 0.577$ & $79.34 \pm 0.584$ & $85.29 \pm 0.556$ & $84.46 \pm 0.602$ \\
\hline $\mathbf{9}$ & $102.32 \pm 0.667$ & $98.42 \pm 0.660$ & $101.75 \pm 0.959$ & $99.45 \pm 0.461$ & $84.21 \pm 0.575$ & $81.35 \pm 0.608$ & $89.16 \pm 0.516$ & $88.57 \pm 0.579$ \\
\hline $\mathbf{1 0}$ & $105.10 \pm 0.900$ & $101.31 \pm 0.715$ & $104.82 \pm 0.781$ & $102.93 \pm 0.443$ & $88.37 \pm 0.611$ & $85.32 \pm 0.663$ & $93.37 \pm 0.558$ & $92.45 \pm 0.561$ \\
\hline F-test & $*$ & $*$ & $*$ & $*$ & $*$ & $*$ \\
\hline C.D@ 5\% & 1.93 & 1.783 & 1.984 & 1.677 & 1.691 & 1.712 & 1.626 \\
\hline C.V.(\%) & 1.222 & 1.16 & 1.266 & 1.083 & 1.299 & 1.35 \\
\hline
\end{tabular}

Each values are the mean \pm SD of 3 replications, $P<0.05 \%$ : Significant $(*), P>0.05 \%$ : Non significant (NS) 
Table.4 Changes in fat body LDH activity level of unmated male moths of selected silkworm races (Each observation are expressed in $\mu$ moles of formazan / g protein / h)

\begin{tabular}{|c|c|c|c|c|c|c|c|c|}
\hline $\begin{array}{c}\text { Races/breeds } \\
\text { Days }\end{array}$ & $\mathrm{CSR}_{2}$ & $\mathrm{NB}_{4} \mathbf{D}_{2}$ & APS45 & APS12 & PM & C.nichi & APM1 & APM3 \\
\hline 1 & $75.53 \pm 0.760$ & $74.35 \pm 0.667$ & $74.89 \pm 0.817$ & $74.47 \pm 0.789$ & $62.54 \pm 0.671$ & $61.23 \pm 0.683$ & $66.43 \pm 0.424$ & $65.73 \pm 0.488$ \\
\hline 2 & $77.29 \pm 0.563$ & $75.41 \pm 0.470$ & $76.61 \pm 1.035$ & $76.51 \pm 0.642$ & $65.57 \pm 0.686$ & $63.63 \pm 0.649$ & $69.16 \pm 0.409$ & $68.40 \pm 0.509$ \\
\hline 3 & $79.33 \pm 0.639$ & $77.44 \pm 0.519$ & $78.24 \pm 0.883$ & $78.47 \pm 0.397$ & $68.48 \pm 0.593$ & $66.48 \pm 0.583$ & $72.03 \pm 0.806$ & $70.48 \pm 0.571$ \\
\hline 4 & $82.46 \pm 0.536$ & $80.69 \pm 0.582$ & $81.36 \pm 0.791$ & $81.26 \pm 0.676$ & $70.47 \pm 0.576$ & $69.46 \pm 0.598$ & $73.07 \pm 1.082$ & $71.37 \pm 0.431$ \\
\hline 5 & $84.30 \pm 0.586$ & $82.52 \pm 0.594$ & $83.97 \pm 0.880$ & $83.26 \pm 0.488$ & $71.36 \pm 0.615$ & $70.46 \pm 0.654$ & $74.32 \pm 0.740$ & $73.53 \pm 0.742$ \\
\hline 6 & $85.49 \pm 0.629$ & $83.62 \pm 0.693$ & $85.27 \pm 0.951$ & $84.26 \pm 0.500$ & $73.32 \pm 0.426$ & $72.44 \pm 0.540$ & $75.51 \pm 0.635$ & $74.88 \pm 0.867$ \\
\hline 7 & $87.21 \pm 0.579$ & $84.46 \pm 0.672$ & $86.44 \pm 1.137$ & $85.37 \pm 0.474$ & $74.45 \pm 0.629$ & $73.25 \pm 0.959$ & $78.41 \pm 0.652$ & $77.42 \pm 0.570$ \\
\hline 8 & $90.38 \pm 0.616$ & $87.45 \pm 0.678$ & $88.97 \pm 0.916$ & $88.36 \pm 0.557$ & $77.47 \pm 0.571$ & $73.25 \pm 3.709$ & $82.51 \pm 0.544$ & $81.61 \pm 0.442$ \\
\hline 9 & $94.27 \pm 0.657$ & $91.39 \pm 0.421$ & $93.23 \pm 0.803$ & $92.35 \pm 0.591$ & 0.000 & $80.52 \pm 0.747$ & $85.55 \pm 0.521$ & $84.43 \pm 0.597$ \\
\hline 10 & $98.21 \pm 0.580$ & $95.31 \pm 0.421$ & $97.32 \pm 0.833$ & $96.43 \pm 0.457$ & 0.000 & 0.000 & 0.000 & 0.000 \\
\hline F-test & $*$ & $*$ & $*$ & $*$ & $*$ & $*$ & $*$ & $*$ \\
\hline C.D@ 5\% & 1.834 & 1.725 & 2.705 & 1.688 & 1.596 & 3.934 & 1.905 & 1.677 \\
\hline C.V. (\%) & 1.252 & 1.208 & 1.864 & 1.171 & 1.65 & 3.636 & 1.64 & 1.464 \\
\hline
\end{tabular}

Each values are the mean \pm SD of 3 replications, $P<0.05 \%$ : Significant $(*), P>0.05 \%$ : Non significant (NS) 
Table.5 Changes in fat body LDH activity level of mated female moths of selected silkworm races (Each observation are expressed in $\mu$ moles of formazan / g protein / h)

\begin{tabular}{|c|c|c|c|c|c|c|c|c|}
\hline $\begin{array}{c}\text { Races/breeds } \\
\text { Days }\end{array}$ & $\mathbf{C S R}_{\mathbf{2}}$ & $\mathbf{N B}_{\mathbf{4}} \mathbf{D}_{\mathbf{2}}$ & APS45 & APS12 & PM & C.nichi & APM1 & APM3 \\
\hline $\mathbf{1}$ & $78.55 \pm 0.683$ & $77.25 \pm 0.647$ & $78.31 \pm 0.467$ & $77.43 \pm 0.483$ & $63.20 \pm 0.572$ & $62.41 \pm 0.537$ & $68.31 \pm 0.585$ & $68.12 \pm 0.534$ \\
\hline $\mathbf{2}$ & $79.60 \pm 0.726$ & $78.30 \pm 0.698$ & $79.07 \pm 0.472$ & $78.55 \pm 0.595$ & $68.07 \pm 0.491$ & $63.40 \pm 0.687$ & $70.29 \pm 0.643$ & $69.23 \pm 0.579$ \\
\hline $\mathbf{3}$ & $81.52 \pm 0.725$ & $79.31 \pm 0.610$ & $81.27 \pm 0.543$ & $80.34 \pm 0.560$ & $69.24 \pm 0.601$ & $65.46 \pm 0.667$ & $72.37 \pm 0.551$ & $71.37 \pm 0.608$ \\
\hline $\mathbf{4}$ & $85.38 \pm 0.456$ & $83.38 \pm 0.534$ & $84.53 \pm 0.644$ & $84.37 \pm 0.705$ & $71.31 \pm 0.556$ & $68.26 \pm 0.605$ & $74.27 \pm 0.715$ & $73.21 \pm 0.566$ \\
\hline $\mathbf{5}$ & $86.67 \pm 0.501$ & $84.35 \pm 0.727$ & $86.26 \pm 0.576$ & $85.59 \pm 0.576$ & $73.37 \pm 0.467$ & $70.20 \pm 0.571$ & $75.43 \pm 0.649$ & $74.40 \pm 0.497$ \\
\hline $\mathbf{6}$ & $88.43 \pm 0.606$ & $86.32 \pm 0.475$ & $88.21 \pm 0.604$ & $86.65 \pm 0.440$ & $74.41 \pm 0.491$ & $71.71 \pm 0.605$ & $77.33 \pm 0.588$ & $76.58 \pm 0.387$ \\
\hline $\mathbf{7}$ & $91.37 \pm 0.684$ & $87.31 \pm 0.588$ & $91.14 \pm 0.545$ & $88.46 \pm 0.687$ & $76.34 \pm 0.569$ & $74.40 \pm 0.600$ & $79.37 \pm 0.497$ & $78.31 \pm 0.577$ \\
\hline $\mathbf{8}$ & $95.32 \pm 0.496$ & $92.49 \pm 0.556$ & $94.34 \pm 0.638$ & $93.45 \pm 0.475$ & $78.35 \pm 0.609$ & $77.14 \pm 0.632$ & $83.70 \pm 0.518$ & $82.31 \pm 0.588$ \\
\hline $\mathbf{9}$ & $98.31 \pm 0.576$ & $95.38 \pm 0.567$ & $98.19 \pm 0.543$ & $96.49 \pm 0.591$ & $82.52 \pm 0.536$ & $79.22 \pm 0.580$ & $86.96 \pm 0.426$ & $85.34 \pm 0.583$ \\
\hline $\mathbf{1 0}$ & 0.000 & 0.000 & 0.000 & 0.000 & 0.000 & 0.000 & $90.26 \pm 0.609$ & $89.13 \pm 0.516$ \\
\hline F-test & $*$ & $*$ & $*$ & $*$ & $*$ & $*$ & $*$ \\
\hline C.D@ 5\% & 1.802 & 1.705 & 1.584 & 1.619 & 1.538 & 1.722 & 1.733 \\
\hline C.V.(\%) & 1.186 & 1.301 & 1.182 & 1.224 & 1.366 & 1.588 & 1.299 \\
\hline
\end{tabular}

Each values are the mean $\pm \mathrm{SD}$ of 3 replications, $\quad P<0.05 \%$ : Significant $(*), P>0.05 \%$ : Non significant (NS) 
Table.6 Changes in fat body LDH activity level of mated male moths of selected silkworm races (Each observation are expressed in $\mu$ moles of formazan/g protein/h)

\begin{tabular}{|c|c|c|c|c|c|c|c|c|}
\hline $\begin{array}{c}\text { Races/breeds } \\
\text { Days }\end{array}$ & $\mathbf{C S R}_{\mathbf{2}}$ & $\mathbf{N B}_{\mathbf{4}} \mathbf{D}_{\mathbf{2}}$ & $\mathbf{A P S 4 5}$ & APS12 & PM & C.nichi & APM1 & APM3 \\
\hline $\mathbf{1}$ & $73.34 \pm 0.478$ & $70.57 \pm 0.679$ & $73.24 \pm 0.973$ & $71.58 \pm 0.711$ & $60.77 \pm 0.482$ & $59.31 \pm 0.446$ & $64.50 \pm 0.613$ & $63.77 \pm 0.682$ \\
\hline $\mathbf{2}$ & $75.18 \pm 0.576$ & $72.35 \pm 0.700$ & $75.03 \pm 0.969$ & $73.45 \pm 0.692$ & $64.37 \pm 0.256$ & $62.46 \pm 0.572$ & $67.03 \pm 0.000$ & $65.93 \pm 0.804$ \\
\hline $\mathbf{3}$ & $78.42 \pm 0.582$ & $76.36 \pm 0.473$ & $78.01 \pm 0.511$ & $76.97 \pm 0.474$ & $65.67 \pm 0.572$ & $64.42 \pm 0.617$ & $69.64 \pm 0.452$ & $68.80 \pm 0.887$ \\
\hline $\mathbf{4}$ & $80.40 \pm 0.590$ & $78.23 \pm 0.681$ & $80.41 \pm 0.738$ & $78.89 \pm 0.527$ & $68.31 \pm 0.578$ & $67.65 \pm 0.714$ & $71.55 \pm 0.637$ & $70.54 \pm 0.638$ \\
\hline $\mathbf{5}$ & $82.47 \pm 0.611$ & $79.40 \pm 0.712$ & $82.20 \pm 0.969$ & $80.53 \pm 0.765$ & $70.49 \pm 0.548$ & $69.47 \pm 0.586$ & $72.77 \pm 0.574$ & $72.22 \pm 0.637$ \\
\hline $\mathbf{6}$ & $84.37 \pm 0.589$ & $81.35 \pm 0.686$ & $83.82 \pm 0.797$ & $82.64 \pm 0.667$ & $71.27 \pm 0.587$ & $70.54 \pm 0.642$ & $74.71 \pm 0.660$ & $73.59 \pm 0.669$ \\
\hline $\mathbf{7}$ & $86.39 \pm 0.457$ & $83.52 \pm 0.597$ & $85.61 \pm 0.514$ & $84.42 \pm 0.724$ & $73.81 \pm 0.596$ & $72.49 \pm 0.663$ & $77.10 \pm 0.676$ & $76.02 \pm 0.764$ \\
\hline $\mathbf{8}$ & $88.25 \pm 0.653$ & $85.29 \pm 0.649$ & $87.63 \pm 0.793$ & $86.16 \pm 0.615$ & $75.71 \pm 0.555$ & $74.60 \pm 0.669$ & $81.61 \pm 0.751$ & $81.27 \pm 0.452$ \\
\hline $\mathbf{9}$ & 0.000 & 0.000 & 0.000 & 0.000 & 0.000 & 0.000 \\
\hline F-test & $*$ & $*$ & $*$ & $*$ & $* .000$ & $83.38 \pm 0.789$ \\
\hline C.D@ 5\% & 1.515 & 1.73 & 2.134 & 1.737 & 1.415 & 1.643 \\
\hline C.V.(\%) & 1.362 & 1.609 & 1.926 & 1.596 & 1.498 & 1.771 & 1.825 \\
\hline
\end{tabular}

Each values are the mean \pm SD of 3 replications, $P<0.05 \%$ : Significant $(*), P>0.05 \%$ : Non significant (NS) 
Figs.1-4 Changes in fat body LDH of male and female pupae of bivoltine and multivoltine silkworm races/breeds.

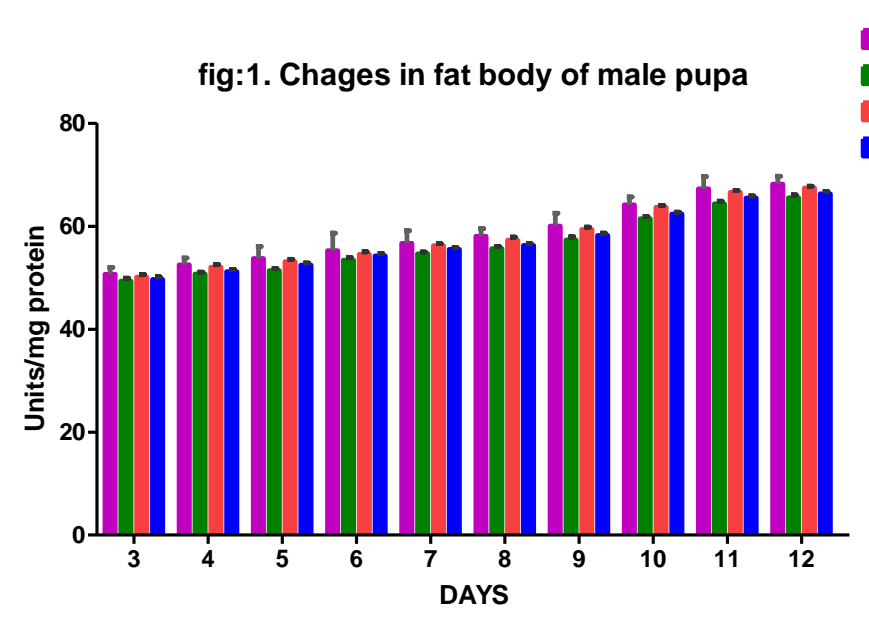

Fig:2. Chages in fat body of male pupa

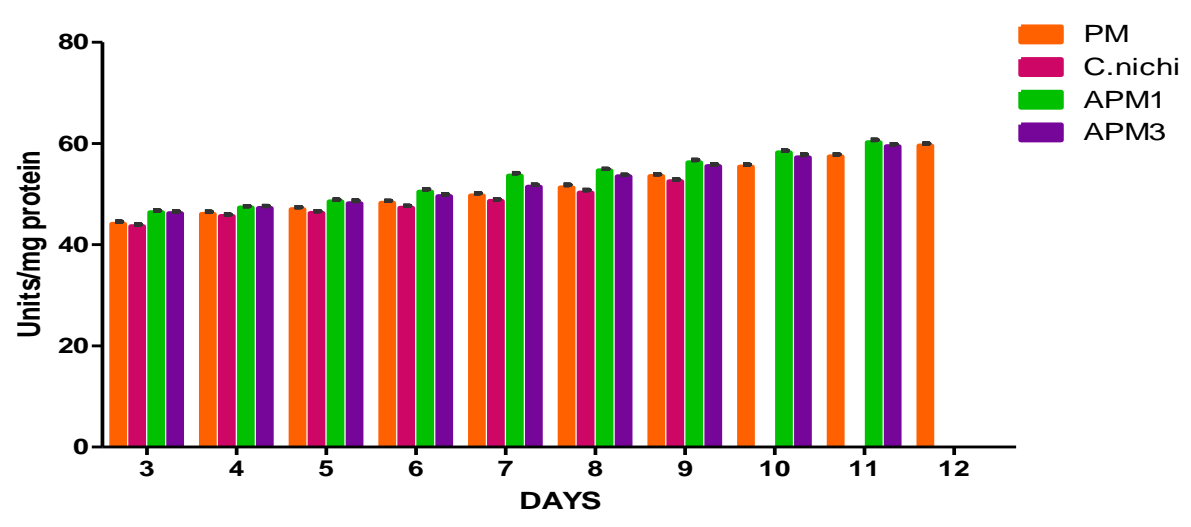

Fig:4. Chages in fat body of female pupa
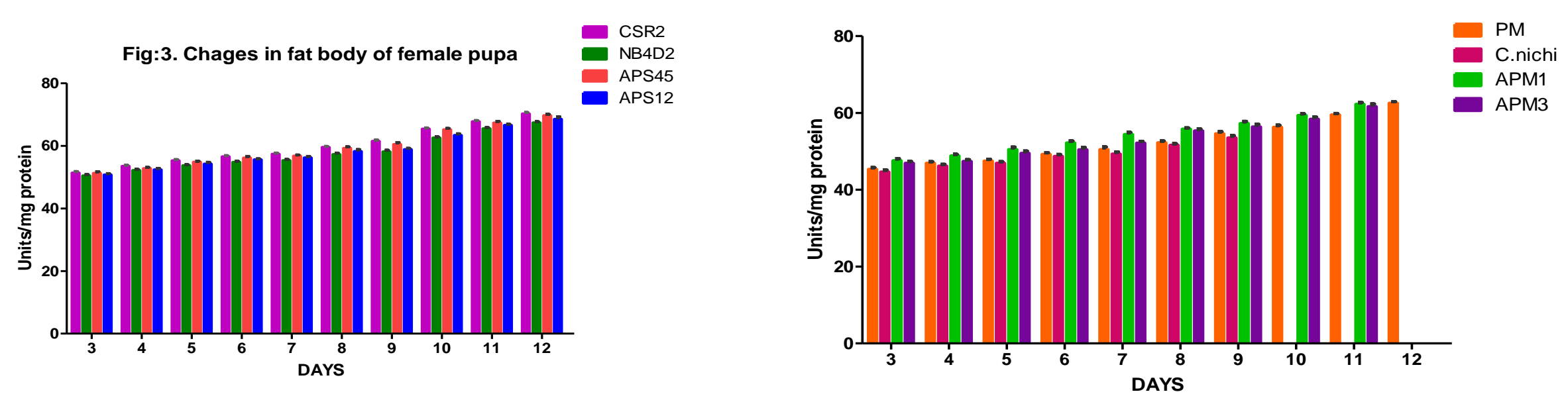
Figs.5-8 Changes in fat body LDH of virgin female and unmated male moth of bivoltine and multivoltine silkworm races/breeds
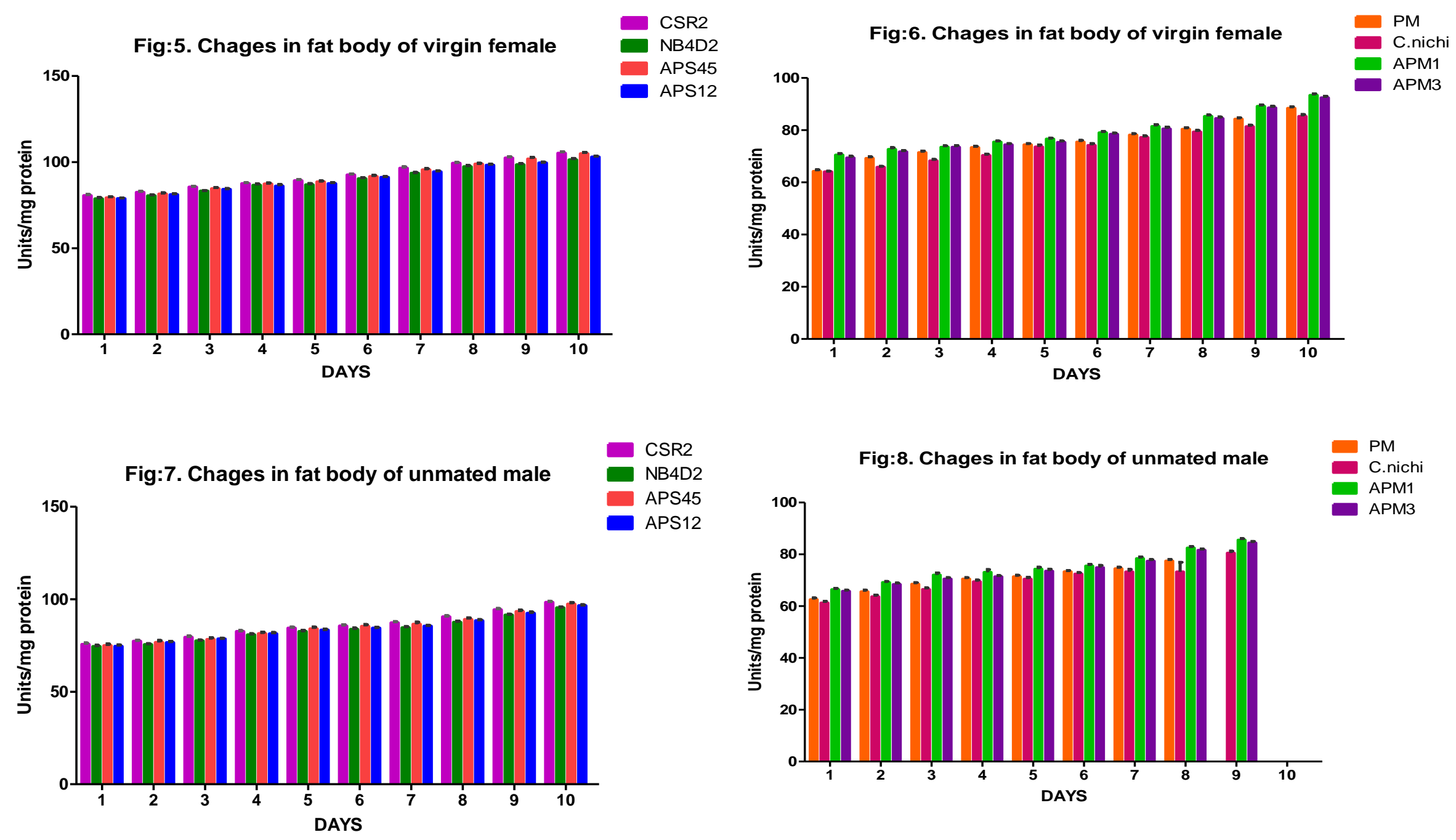
Figs.9-12 Changes in fat body LDH of mated female and male moth of bivoltine and multivoltine silkworm races/breeds
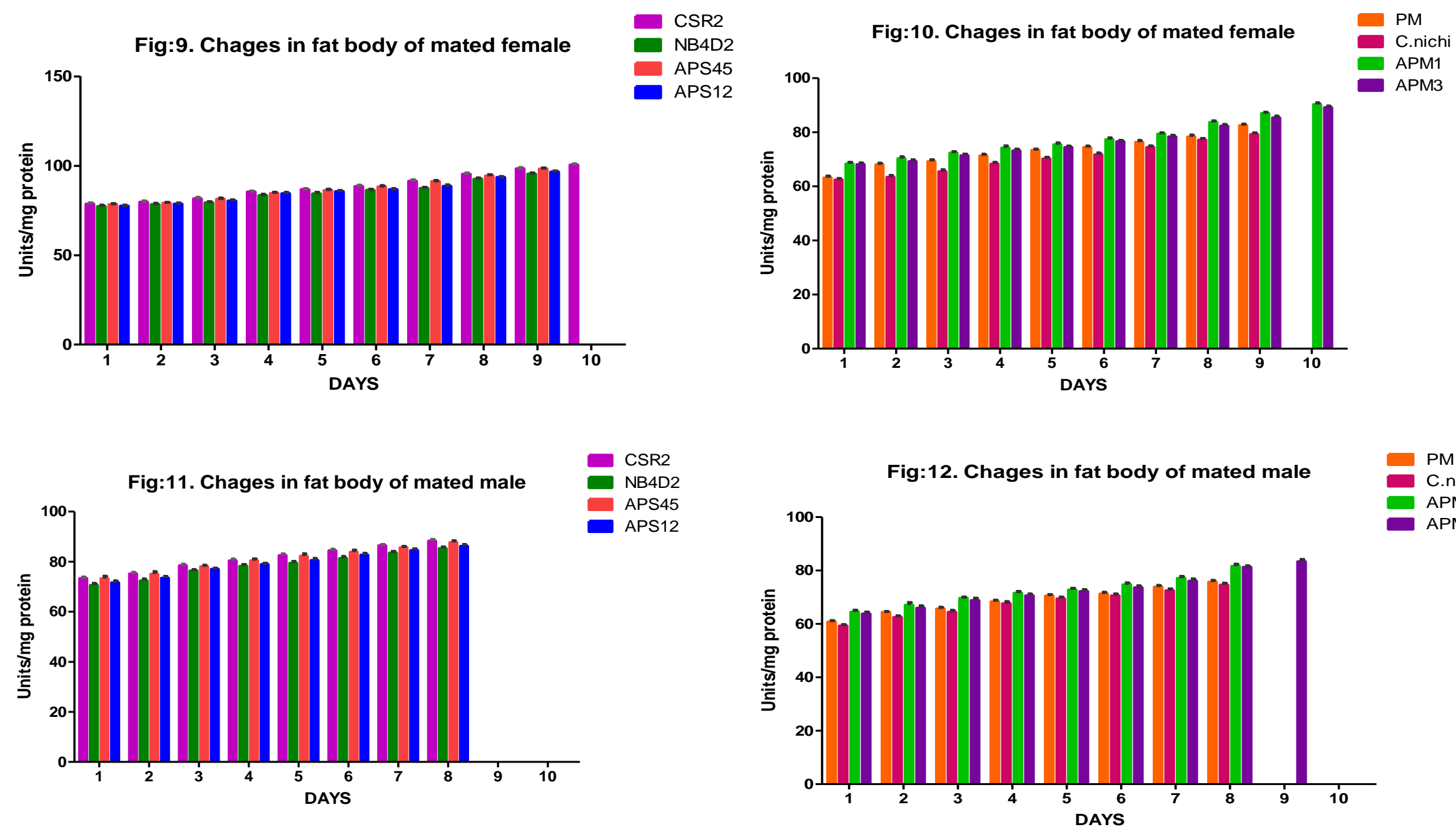
Thus the activity of enzymes belonging to different metabolic route but competing for common substrate appears to be an important factor determining the metabolic rate of the substrate. The enzyme activity of succinate dehydrogenase and lactate dehydrogenase in the fat body, testis and seminal vesicle of nimbecidine treated insects were gradually decreased than the control insects. In contrast, the activity of malate dehydrogenese and glutamate dehydrogenase in the fat body, testis and seminal vesicle of nimbecidine treated insects were gradually increased than the control insects. This observation is in conformity with Sumathi (2002), Rajathi (2004), Ramesh Kumar (2004), Lousia (2010), Riseh et al., (2012) and Mostafa S. Abd ElNaby and Ehab Wafeek Zidan (2014). In general, any stress inducing substance will affect the respiratory metabolism of insect. Any alteration in the intermediary metabolism due to stress is bound to affect the activity of oxidative enzymes like succinate dehydrogenase and lactate dehydrogenase etc. Nevertheless, the lactate dehydrogenase is an important glycolytic enzyme which is present virtually in all invertebrate tissues (Kaplan and Pesce, 1996).

Dehydrogenases are very important tools for the investigation of insect metabolic activities during the course of development. The relative activities of the insect dehydrogenases may be related to the function and energy yielding demands of the tissues (Dickinson and Sullivan, 1975). Lactate dehydrogenase (LDH) is an important glycolytic enzyme that is present in virtually all tissues (Kaplan and Pesce, 1996 and Shekari et al., 2008). It is involved in carbohydrate metabolism and has been used as an indicative criterion of exposure to chemical stress (Diamantino et al., 2001). Lactate dehydrogenase is, also, a parameter widely used in toxicology and in clinical chemistry to diagnose cell, tissue and organ damage. However, the potential of this enzyme as an indicative criterion in the invertebrate toxicity tests has been scarcely explored (Ribeiro et al., 1999, Nathan et al., 2006b and Riseh et al., 2012), in addition to its role as an evidence for an alternative pathway of terminal anaerobic metabolism (Bianconcini et al., 1980).

The present inhibitory effects of the phytopesticide nimbecidine are in agreement with those inhibitory effects of some insecticides and insect growth regulators (IGRs) on the LDH activity in fat bodies of other insects species such as the house fly Musca domestica (Hassanein et al., 1996), the silkworm, Bombyx mori (Nath, 2000), a susceptible strain of the mosquito $C$. fatigans (Azmi et al., 2002), the rice leaf folder Cnaphalocrocis medinalis (Nathan et al., 2004), the cotton leafworm S. littoralis (Abdel-Ghaffar and Basiouny, 2007). Investigating the inhibitory effect of certain $A$. indica extracts on lactate dehydrogenase in another tissue, mid-gut of $C$. medinalis, Senthil Nathan et al., (2006b) observed a decrease in the enzyme activity denoting a reduced metabolism in the insect and may be due to the toxic effects of neem derivatives on membrane permeability, especially on the gut epithelium (Nathan et al., 2004 and 2005 and Smirle et al., 1996).

\section{Acknowledgements}

The authors wish to express sincere thanks to University Grants Commission for providing the funds. We wish to thank the Chairman, Department of Studies in Sericulture Science, Manasagangotri, University of Mysore, Mysore for extending the laboratory facilities to carry out the research work.

\section{References}

Abdel-Ghaffar, A. A. and Basiouny, A. L. (2007) Response of malate and lactate dehydrogenase activity in larvae of 
Spodoptera littoralis (Boisd.) by antijuvenile hormone precocene I. J. Biol. Pharm. Sci., 1: 13-20.

Alexandrov, V. Y. (1977) Cells, Molecules and Temperature. Springer Verlog, Berlin, Heidelberg and New York.

Azmi, M. A.; Ahmad, I.; Naqvi, S. N. H. and Akhtar, K. (2002) Level of lactate dehydrogenase (LDH) in resistant and susceptible strains of Culicine mosquitoes of the Karachi region after treatment with DDT, malathion and cyfluthrin. Turk J. Zool., 26: 97-100.

Bianconcini, M. S. C.; Mederiros, L. O.; Mederiros, L. F.; Mendes, E. G. and Valenti, D. (1980) Glycolytic and hexose monophosphate enzyme activities in the latern muscles of the sea urchins, Arbacia lexula (Linn.), Echinometra lucunter (Linn.) and Lytechinus variegates (Lamark). Comp. Biochem. Physiol., 67(B): 569-57.

Chefurka, W. (1965) Physio of insecta; academic press, New York and London.

Diamantino, T. C.; Almeida, E.; Soares, A. M. and Guilhermino, L. (2001) Lactate dehydrogenase activity as an effect criterion in toxicity tests with Daphnia magna straus. Chemosphere, 45(4): 553560.

Dickinson, W. J. and Sullivan, D. T. (1975) Geneenzyme systems in Drosophila. New York: Springer-Verlag., 34-40.

Hassanien, A. H. M.; Baker, R. F. A.; Saleh, N. A. and El-Bermawy, S. M. (1996) Biochemical aberrations induced by three insect growth regulators in the house fly Musca domestica L. (Diptera: Muscidae). Ain. Shams Sci. Bull., 34: 319-350.

Kaplan, L. A. and Pesce, A. J. (1996) Clinical Chemistry-theory Analysis and Correlation. Mosby-Year Book, MO. 609610.

Kumar, S and Ehteshamuddin, S. (2001) Effect of corpus allatum hormone and brain on LDH activity in cybister confuses. J. Natcon.

Katunuma, N.; Okada, M.; Katsunuma, T.; Fujino, A. and Matsuzawa, T. (1968) Different metabolic rates of transaminase isozymes. In: Pyridoxal Catalysis, Enzymes and
Model Systems. (Eds. E.E. Suell, A.E. Braunstein, E.S. Sevcrin and Y.M. Torchinsky). Inter-Science Publication, New York.

Krishnaswami, S. (1978) New techniques of silkworm rearing. CSRTI Bulletin, CSRTI, Mysuru, India, 2: 1-23.

Lousia, M. (2010). Studies on the impact of pydidial secretion on certain selected tissues in the adult male insect Odontopus varicornis (Dist.) (Heteroptera: Pyrrhoridae) in relation to reproduction. Ph.D., Thesis, Annamalai University, Tamilnadu.

Mostafa, S.; El Naby, A. and Zidan, E. W. (2014) Activity level of lactate dehydrogenase and $\beta$-glucosidase enzymes in the honeybee colonies (Apis mellifera L.) with different feeding with different feeding, Egypt. Acad. J. Biolog. Sci., 6(1): 93-100.

Nath, B. S. (2000) Changes in carbohydrate metabolism in hemolymph and fat body of the silkworm, Bombyx mori L., exposed to organophosphorus insecticides. Pestic. Biochem. Physiol., 68: 127-137.

Nathan, S. S.; Chung, P. G. and Murugan, K. (2004) Effect of botanical insecticides and bacterial toxins on the gut enzyme of the rice leaf folder Cnaphalocrocis medinalis. Phytoparasitica, 32(5): 433-443.

Nichlas, M. M.; Magulies, S. I. and Seligman, A. M. (1960) Sites of electron transfer to tetrazolium salts in the succinoxidase system. J. Biol. Chem., 235: 2739-2743.

Rajathi, (2004) Studies on the impact of heavy metal mercury in the adult male reproductive Physiology of Sphaerodema rusticum (Heteroptera: Belostomatidae) Ph.D., Thesis, Annamalai University, India.

Ramesh Kumar, T. (2004) Studies on the impact of heavy metal zinc on certain selected tissues in the adult male Laccotrephes rubber (Linn) (Heteroptera; Nepidae) in relation to reproduction Ph.D, Thesis, Annamalai University, India.

Reddy, K.V.R. and Benchamin, K.V. (1992) Heat shock effect on testicular composition: A biochemical study in silkworm, Bombyx mori. Proc. Indian Natl. Sci. Acad., 58(6): 329-332. 
Rekha S. Misbahuddin and Ehteshamuddin, S. (2000) Effects of Phosphamidol on the Alkaline phosphatase Activity in the Haemolymph of sap feeding insect pests Aspongopus and Janus, Crysocoris stollii and Dysdercus cingutus. Environ. Ecology.

Ribeiro, S.; Guilhermino, L.; Sousa, J. P. and Soares, A. M. V. M. (1999) Novel bioassay based on acetylcholinesterase and lactate dehydrogenase activities to evaluate the toxicity of chemicals to soil isopods. Ecotoxicology and Environmental Safety, 44(3): 287-293.

Riseh, N. S.; Ghadamyari, M. and Motamediniya, B. (2012) Biochemical characterization of $\alpha \quad \& \quad \beta$-glucosidasesand $\alpha \quad \& \quad \beta$ galactosidases from red palm weevil, Rhynchophorus ferrugineus Olivieri (Col.:Curculionidae), Plant. Protect. Sci., 2: 85-93.

Riseh, N. S.; Ghadamyari, M. and Motamediniya, B. (2012) Biochemical characterization of $\alpha \& \beta$-glucosidases and $\alpha$ \& $\beta$ galactosidases from red palm weevil, Rhynchophorus ferrugineus Olivieri (Col.:Curculionidae), Plant. Protect. Sci., 2: 85-93.

Rockstein, M. and Miquel, J. (1973) The physiology of insect Vol. 1 (Aging in insects, chapter-6), ICB. Oxford journal, 371-469.

Sacktor, B. (1974) Biological oxidation and energetics in insect mitochondria. In: The Physiology of Insecta (Ed. M. Rockstein). Academic Press, New York, 4: 271-353.

Sen, S.K.; Sengupta, A.K. and Jolly, M.S. (1976) Studies on genetic variability of some economic traits in Antheraea mylitta D. Indian J. Seric., 15: 9-14.

Shekari, M.; Sendi, J. J.; Etebari, K.; Zibaee, A. and Shadparvar, A. (2008) Effects of Artemisia annua L. (Asteracea) on nutritional physiology and enzyme activities of elm leaf beetle, Xanthogaleruca luteola Mull.(Coleoptera: hrysomellidae). Pesticide Biochemistry and Physiology, 91(1): 66-74.

Siddiqui, A.A.; Debnath, A.K. and Sengupta, K. (1984) Variation and correlation studies on shell weight and their contributing traits in Antheraea mylitta D. Sericologia, 25: 45-50.

Smirle, M. J.; Lowery, D. T. and Zurowski, C. L. (1996) Influence of Neem oil on detoxification enzyme activity in the oblique banded leafroller, Choristoneura rosaceana. Pestic. Biochem. Physiol., 56: 220-230.

Somme, L. (1972) The effect of acclimation and low temperature on enzyme activities in larvae of Ephestia kuehniella Zell. (Lepidoptera: Pyralidae). Entomol. Scand., 3: 12-18.

Srivastava, R.; Sharma, S.; Shah, U. N. and Ehteshamuddin, S. (1991) Protein, free amino acids and glycogen in the haemolymph and fat body to Hydrophilous olivaceous in relation to strarvations. J. Fresh water Biol.

Sumathi. (2002) Studies on the impact of endosulfan on certain selected tissues of the adult male insect Gryllotalpa africana (Palisot de Beaurols) (Orthoptera: Gryllotalpidae) in relation to reproduction Ph.D., Thesis, Annamalai University. India.

Tazima, Y. (1978) The Silkworm an important laboratory tool. National Institute of Genetics Kodansha Tokyo, Japan.

Zebe, E. C. and McShan, W. H. (1957) Lactic and alpha-glycerophosphate dehydrogenases in insects. J. Gen. Physiol., 40: 779-790.

\section{How to cite this article:}

Ramya, M.N. and Jagadeesh Kumar, T.S. 2019. Studies on Lactate Dehydrogenase (LDH) Activity in the Pupal and Adult Stages of the Silkworm Bombyx Mori L. Int.J.Curr.Microbiol.App.Sci. 8(11): 2487-2502. doi: https://doi.org/10.20546/ijcmas.2019.811.287 